Vol.1, No.1, Issue.1, pp.12-19, 2019

\title{
Market Orientation and Business Performance: Study in Petrol Station in Timor-Leste
}

Estanislau de Sousa Saldanha ${ }^{1}$, Elizita Vilhena Gusmao ${ }^{1}$, Domingos M.B. Barreto ${ }^{1}$, Jorge Ribeiro Freitas ${ }^{1}$, Teresa Freitas Belo ${ }^{1}$ Dili Institute of Technology, Timor-Leste

Email : estanislausaldanha@yahoo.com

\begin{abstract}
S
The objective of this research is to assess the impact of market orientation on business performance in the petrol stations in Timor-Leste. In our study, we used questionnaire from previous authors to collect data. Hypothesis was tested using Smart-PLS 3.0. The result shows that market orientation reflected by consumer orientation, competitor orientation, and inter-functional coordination had a positive and significant impact on business performance. This study contributes to the literature on market orientation and business performance which still face inconsistent results from previous researches. This study is also expected to be considered by the government in developing policies related to small and medium enterprise (SMEs) management. In the middle of this, market orientation could be one determinant factor to be considered as strategic fitness to improve SME's financial and nonfinancial performances in TimorLeste. In addition, SME's managers could look at market orientation as a business strategy to improve their business performance.
\end{abstract}

Keywords : Market orientation, business performance, petrol station, Timor-Leste.

\section{INTRODUCTION}

Increasing recent high industrial competition and environmental uncertainty, firms are trying to retain their sustainable growth by adopting market orientation strategy. In this situation, customers' demands change quite intensely pushing firms to consider modifying their products and services continually to be able to satisfy the changing choices of customers (Andotra \& Gupta, 2016). Therefore, firms place the customer's interests at the center of its tactics and beliefs and focuses on learning about customers, competitors and environment (Narver \& Slater, 1990; Salehzadeh et al., 2017). Firms are also required to closely monitor customer needs, competitor actions, and consolidate their internal resources in order to be able to create and offer innovative products or services with value, quality and price fitting to the customer demands (Narver \& Slater, 1990), which is ultimately enhancing firm's competitive position and sustainable performance (Mahmoud et al., 2016).

The conceptual views on the influence of the market orientation on firm performance have been well-noted. However, the reality of empirical studies reveals that, there is a variety of results, in addition to the limited understanding about the precise nature of the influence of market orientation on competitive advantage (Osorio et al., 2019) and firm performance (Lim et al., 2017). Numerous empirical studies confirm that market orientation strengthens business performance (Nguyen, 2018; Abbu \& Gopalakrishna, 2019; Sampaio et al., 2019), while other studies also show that market orientation have insignificant impacts on the business performance (Kajalo \& Lindblom, 2015), and/or negative impacts on business performance (Acosta, Crespo, \& Agudo,
2018; Idrus, Ahmar, \& Abdussakir, 2019).

The inconsistency results of empirical studies leave significant spaces for researchers to explore possible dimensions and indicators to use in specific industries, aiming to enhance firm competitive position and performance. This study aims to fill up the abovementioned empirical gap and the absence of empirical study on the impact of market orientation on business performance in Timor-Leste. It can also contribute to the government in considering market orientation as an alternative option in developing strategy for small and medium enterprises (SMEs) in transition economy. Firm managers can also be benefited by this research through considering the importance of costumer's demands, market intelligence and internal resource consolidation as basis for offering products and services in order to be able to sustain high competitive advantages and retain firm performance in dynamic change of market environment. This could be in line with Osorio et al. (2019) states that firm only focuses on exploitation activities is possibly ineffective in dealing with the recent market demands because of its limited new ideas and strategies.

\section{TEORITICAL FRAMEWORK AND HYPOTHESIS}

\subsection{Market Orientation}

The recent intensely and dynamic industrial competition forcing companies to consolidate their internal capabilities in developing strategy based on market intelligence and customer demands (Andotra \& Gupta, 2016). Firms try to integrate customer needs into their organization culture, value and trust (Jogaratnam, 2017) which generally call market orientation. Market orientation has two approaches namely behavioral 
approach and cultural approach (Protcko \& Dornberger, 2014; Śályová et al., 2015; Mahmoud et al., 2016).

In the behavior approach, the market orientation has three behavior components namely intelligence generation, intelligence dissemination and responsiveness (Kohli \& Jaworski, 1990). This approach requires firms to carry out environmental scanning activities which include monitoring government regulation, technology, competitors, and other environmental force in order to be able to anticipate customers' demands (Gligor, Gligor, \& Maloni, 2019).

In the cultural approach, market orientation has three dimensions such as customer orientation, competitive orientation and inter-functional coordination (Narver \& Slater, 1990). In this approach, firms fully consolidate their internal resources and capabilities to understand costumer needs and competitor actions in order to create and offer products or services to the target costumers (Salehzadeh et al., 2017). Therefore, firms need to fully understand what buyers currently value and how this will evolve over time in dynamic markets (Gligor et al., 2019).

Market orientation needs the consistency of firms to monitor their customers' needs, the change of customer satisfaction, the increasing rate of product innovation, and adoption of strategic fitness, leading to the strengthen firms' competitive advantages (Mahmoud et al., 2016). Following this rule, firms should develop their unique strategy and internal resources and capabilities in human resources, technology, market network, and financial access to offer innovative products and services in responding to the dynamic and fast changes in customers' needs (Porter, 1980; Barney, 1991). To this, market orientation becomes one of determinant factors to select and implement business strategy, aiming to enhance market position and firm performance (Iyer et al., 2019). The basic view of this concept is that market oriented firms should have strong competitive position compared to its rivals by quickly responds to the changing demands of costumers (Jiang et al., 2019).

\subsection{Business Performance}

Business performance is a multidimensional concepts which reflects from financial and market dimensions (Nguyen, 2018). Business performance is as an important parameter to measure the achievement of objectives of business organization from both financial and non-financial perspectives (Yadav, Tripathi, \& Goel, 2019). Zehir, Can, \& Karaboga (2015) noted that financial performances measured by profitability, sales growth, return on investment (ROI), return on sales (ROS) and return on equity (ROE), while nonfinancial performances measured by quality, market share, customer satisfaction, new product development and market effectiveness.

\subsection{Market Orientation and Business Performance}

The core foundation of market orientation to enhance firm's performance is that firms needs to quickly response to the dynamic and continuous changes of costumer's demands, and closely monitor competitor actions using its internal resources and capabilities to create and offer products or services to the needs of the target customers (Narver \& Slater, 1990; Barney, 1991). By quickly responds to costumer demands, a firm will have a better competitive position, leading to acquire large market shares and high profit growth compared to its rivals. Therefore, market orientation has been considered as a major foundation of business management and strategic approaches to enhance firm's performance (Salehzadeh et al., 2017). Market orientation concerns corporate culture, behaviors, values, systems, strategies, principles and norms, which enable a firm to create superior value for customers and thereby increase its performance (Oduro \& Haylemariam, 2019).

Numerous empirical studies have tried to investigate the relationship between market orientation and firm performance (Idrus et al., 2019; Iyer et al., 2019; Köhr et al., 2019; Yadav et al., 2019). The focus of these studies on market orientation as direct antecedent, or as mediation and moderation variables, aiming to explore various dimensions and indicators as an alternative strategy to enhance firm competitive position and performance. These empirical studies reveals that, there are inconsistent results (Mahmoud et al., 2016) due to the limited understanding about the precise nature of the influence of market orientation on competitive advantage (Osorio et al., 2019) and firm performance (Lim et al., 2017). For example a group of researchers have found that market orientation strengthens business performance (Nguyen, 2018; Abbu \& Gopalakrishna, 2019; Sampaio et al., 2019), while other studies also show that market orientation have insignificant impacts on the business performance (Kajalo \& Lindblom, 2015), and/or negative impacts on business performance (Acosta et al., 2018; Idrus et al., 2019).

\subsection{Hypothesis Development}

Firms can make internal consolidation to create new products and services with high value based on customers demand. For this reason, firms need to improve their human capital to create and offer new value, increase benefits and price reduction of products/services to the customers (Jyoti \& Sharma, 2012). Firms that implement market orientation are predicted to perform better because they have the highest level of market-sensing and customer-linking capabilities compared to emergent and inactive forms that lack these capabilities (Abbu \& Gopalakrishna, 2019). Many studies confirm that market orientation strengthens business performance (Rodrigues \& Pinho, 2010; Andotra \& Gupta, 2016; Nguyen, 2018; Abbu \& Gopalakrishna, 2019; Sampaio et al., 2019). Therefore, we formulate the following hypothesis:

$H_{1}$ : The market orientation had a positive and significant
impact on business performance.

\section{METHODOLOGY AND DATA COLLECTION}

The target group was fuel stations that operate in TimorLeste. The Fuel Stations are divided into three regions such as 
(1) East is represented by Baucau \& Manaututo Municipalities, (2) Central is represented by Dili and Ermera Municipalities and (3) West is represented by Liquica \& Bobonaro Municipalities.

We used questionnaire to collect data. This data collection instrument is adopted from Narver \& Slater (1990), Huhtala et al. (2014), Nguyen (2018) for market orientation, and Protcko \& Dornberger (2014), Ozdemir et al. (2017), Nguyen (2018), and Saldanha et al. (2019) for business performance. We used a 5 Likert scale questionnaire ranging from 1(strongly disagree) to 5 (strongly agree).

We used smart-partial least square (Smart-PLS 3.0) to test the data due to this statistical computer software is commonly used to analysis multi-variables relationship in management and business areas (Valaei, 2017), non-normal data, small sample size, and formative or reflexive indicators ) (Hair et al., 2014; Hopkins, 2015). Reliability test was done by using cronbach alpha (CA) with threshold value is above 0.7 and composite reliability (CR) with the threshold value is above 0.7 (Hair et al., 2017). Validity test used convergent validity and discriminant validity. The convergent validity used outer loading (OL) with the threshold value is above 0.7 , and average variance extracted (AVE) with the threshold value is above 0.5) (Hair et al., 2017; Saldanha et al., 2019). Discriminant validity test used Fornell and Larcker criterion, cross-loading (Hair et al., 2014; Hopkins, 2015), and heterotrait-monotrait (HTMT) with maximum values of all indicators are lower than 0.85 (Henseler et al., 2015).

To test hypothesis, we used $\mathrm{T}$ and $\mathrm{P}$ values to assess the significance impacts between market orientation and business performance. We used bootstrapping from SMART-PLS 3.0 to test the hypothesis. If $\mathrm{T}$ values is higher than 1.96 and $\mathrm{P}$ values are lower than 0.05 , then the two variables have significant relationship (Hair et al., 2017; Idrus et al., 2019; Saldanha et al., 2019).

\section{RESULTS}

\subsection{Demographic Characteristics}

The total respondent was 39 from three regions (Eastern, Central and Western) in Timor-Leste. The Eastern region represented by Baucau and Mananuto Municipalities, Central region represented by Dili, Ermera, and Aileu Municipalities, and the Western region represented by Liquica and Bobonaro Municipalities. From this, female $(23.3 \%)$ and male (76.6\%), age from $20-25(10 \%)$, age from $26-30(40 \% \%)$, age from $31-$ $35(20 \% \%)$, age from $35-40(3.3 \%)$ and $>40$ years old (26.7\%). From our study found that the majority of fuel stations earned monthly average incomes of more than $\$ 10,000$ $(80 \%)$ and \$5000-10,000 (20\%) (Table 4.1).

4.1. Table of respondents demographic characterist
\begin{tabular}{|l|c}
\multicolumn{1}{|c}{ Characteristics } & Frequency $(\%)$ \\
\hline Gender & \\
\hline Female & 23.3 \\
\hline Male & 76.7 \\
\hline Total & 100 \\
\hline Age & 10 \\
\hline $20-25$ years old & 40 \\
\hline $26-30$ years old & 20 \\
\hline $31-35$ years old & 3.3 \\
\hline $36-40$ years old & 26.7 \\
\hline More than 40 years old & 100 \\
\hline Total & \\
\hline Monthly Income & 0 \\
\hline Less than $\$ 1000$ & 0 \\
\hline$\$ 1000-5000$ & 20 \\
\hline$\$ 5001-10,000$ & 80 \\
\hline More than $\$ 10,000$ & 100 \\
\hline Total & \\
\hline
\end{tabular}

\subsection{Reliability and Validity Test \\ 4.2.1. Reliability}

Generally, the reliability test is measured by Cronbach alpha (CA), and composite reliability (CR). An indicator is said to be reliable if the CA value is higher than 0.7 , and CR value is higher than 0.7 (Hair et al., 2010; Hair et al., 2014; Hopkins, 2015). Nonetheless, for the exploratory research, the threshold values of CA and CR values are acceptable at the range of above 0.6 (Saldanha et al., 2018). From the reliability test, the CA and CR values of all indicators are higher than 0.6 as shown in Table 4.2 which mean that our model is reliable to predict the relationship between market orientation and business performance.

Table 4.2. Results of Reliability Test

\begin{tabular}{lccc}
\multicolumn{1}{c}{ Parameter } & $\begin{array}{c}\text { Cronbach's Alpha } \\
(\mathrm{CA})\end{array}$ & $\begin{array}{c}\text { Composite Reliability } \\
(\mathrm{CR})\end{array}$ & $\begin{array}{c}\text { Average Variance } \\
\text { Extracted } \\
\text { (AVE) }\end{array}$ \\
\hline Costumer orientation $\left(\mathrm{OM}_{1}\right)$ & 0.78 & 0.84 & 0.64 \\
Competitor orientation $\left(\mathrm{OM}_{2}\right)$ & 0.62 & 0.84 & 0.72 \\
Inter-functional coordination $\left(\mathrm{OM}_{3}\right)$ & 0.79 & 0.88 & 0.7 \\
Financial performance $\left(\mathrm{DB}_{1}\right)$ & 0.95 & 0.97 & 0.88 \\
Non-financial performance $\left(\mathrm{DB}_{2}\right)$ & 0.87 & 0.91 & 0.72 \\
\hline
\end{tabular}


Vol.1, No.1, Issue.1, pp.12-19, 2019

\subsubsection{Validity}

\section{Convergent validity}

Convergent validity is measured by outer loading (OL) and average variance extracted (AVE). OL and AVE of all indicators are valid if the OL values exceed the threshold value of 0.7 and AVE value exceeded of 0.5. However for exploratory research, the OL value of all indicators are above 0.6 could be acceptable (Hair et al., 2017; Saldanha et al., 2019). From figure 1 shows that the OL values of all indicators are higher than the threshold value of 0.6. This means that all indicators are validly used to predict the relationship between variables in this model.

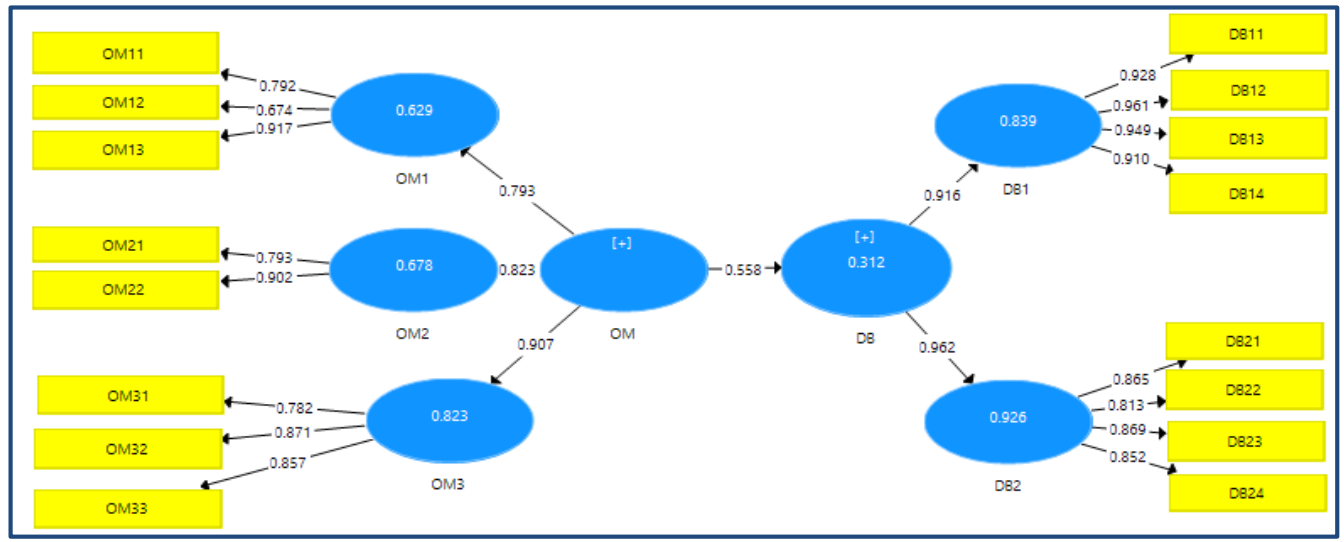

Figure 1. Convergent validity which measure by outer loading.

\section{Discriminant validity}

Discriminant validity is measured by two parameters namely cross-loading and heterotrait-monotrait ratio (HTMT). In terms cross-loading, values from indicators are greater than cross-loading indicators in other dimensions (Appendix C), while HTMT values of all indicators are below than 0.85 (Table 4.3) which mean that this model is valid to predict the relationship between the variable in the inner model.

Table 4.3. Value of heterotrait-monotrait ratio (HTMT)

\begin{tabular}{|c|c|c|c|c|c|}
\hline & $\mathrm{DB}_{1}$ & $\mathrm{DB}_{2}$ & $\mathrm{OM}_{1}$ & $\mathrm{OM}_{2}$ & $\mathrm{OM}_{3}$ \\
\hline \multicolumn{6}{|l|}{$\mathrm{DB}_{1}$} \\
\hline $\mathrm{DB}_{2}$ & 0.75 & & & & \\
\hline $\mathrm{OM}_{1}$ & 0.272 & 0.474 & & & \\
\hline $\mathrm{OM}_{2}$ & 0.336 & 0.283 & 0.828 & & \\
\hline $\mathrm{OM}_{3}$ & 0.488 & 0.652 & 0.635 & 0.85 & \\
\hline
\end{tabular}

\subsection{Hypothesis Test}

The result of the hypothesis test shows that $\mathrm{T}$ value (2.75) is greater than 1.96 and $\mathrm{P}$ value is smaller than 0.05 (see Table 4.4). This means that market orientation had a positive and significant impact on the business performance of Fuel Stations in TimorLeste. Therefore, our hypothesis $(\mathrm{H})$ is accepted.

Table 4.4. Result of Path Coefficient Test (Hypothesis)

\begin{tabular}{|c|c|c|c|c|c|c|}
\hline & Original Sample & $\begin{array}{c}\text { Sample } \\
\text { Mean }\end{array}$ & $\begin{array}{c}\text { Standard } \\
\text { Deviation }\end{array}$ & T Statistics & P Value & Note \\
\hline OM --> DB & 0.558 & 0.602 & 0.197 & 2.785 & 0.004 & Significant \\
\hline
\end{tabular}




\section{DISCUSSIONS}

This study examines the relationship between market orientation on business performance in the context of fuel station businesses in Timor-Leste. The result shows that market orientation has significant effect on business performance. This means that fuel station businesses understand and continuously offer products/services with superior values to the target costumers over time in dynamic markets in order to sustain their business performance (Gligor et al., 2019). The results also reveal that inter-functional coordination and competitor orientation have significant contribution to market orientation compared to costumer orientation. Nonetheless, the values of outer loading of the three dimensions within market orientation almost same which mean they have equally contributions to business performances reflected by financial (e.g. ROI, profit growth, sales growth, and total profitability) and non-financial (e.g. costumer's satisfaction, loyalty, increasing new costumers and market share) in fuel station businesses in Timor-Leste. In this regard, firms are considered to be able to identify customer needs and then wisely utilize their internal capabilities to create and offer products/services based on the target customer demands (Mahmoud, Blankson, Owusu-frimpong, et al., 2016). In addition, many fuel stations in Timor-Leste are categorized as small and medium enterprise (SME) with less formal organization structure which implies to their direct relationship with the costumers. Therefore, their outcome level may face lesser impacted by industry competition as agued by Yadav et al. (2019).

The result of this research is consistent with researches conducted by Narver \& Slater (1990); Jyoti \& Sharma (2012); Š́lyová et al. (2015); Rodrigues \& Pinho (2010); Andotra \& Gupta (2016); Nguyen (2018) that market orientation influences significantly on corporate performance. However, this research differs from previous research findings that market orientation insignificantly influenced (Kajalo \& Lindblom, 2015), or negatively influenced on firm performances (Acosta et al., 2018; Idrus et al., 2019).

The differed results of researches are possibly due to: First, researchers carry out their researches in industries with different sizes, types, products/services (Saldanha et al., 2019), industry environments, strategies (Porter, 1980) and resources and capabilities (Barney, 1991). As stated by Porter (1980) that different industry environment and strategy lead to different competitive advantages and performances. Industries which are able to employ strategic fitness to dynamic environment will be able to sustain their competitive advantages, leading to higher performances compared to their competitors. In addition, different resources and capabilities of firms also lead to different performance. Resource-based theory states that firms with better resources and capabilities are able to outperformance their competitors, retaining their competitive position by continuously creating and offering products/services according to the dynamic and quickly changes of the target customer demands (Barney, 1991). Second, researchers use the different sample sizes, data collection instruments, and analysis which could also contribute to the different research results.

\section{CONCLUSIONS AND IMPLICATIONS}

Our results show that market orientation has a positive significant impact on business performance. The interfunctional coordination and customer orientation have more significant impacts on the business performance compared to competitor orientation. The results of the study confirm the previous works in regard market orientation and corporate performance.

The study contributes empirically to enrich the discussion on market orientation and corporate performance, particularly in the context of emerging markets. Practically, the study also provides to business owners in emerging market to consider costumer orientation, competitor orientation and internal resource consolidation to offer their products and services in gaining high competitive advantages, leading to achieve sustainable performances in dynamic and intensely market competition.

\section{LIMITATION AND FUTURE RESEARCH}

This study is not exempt from limitations. First, this study only uses small size of sample, which might not precisely represent the total population for better generalization. Therefore, we recommend to increasing the number of sample for future research. Second, this research only uses questionnaire as data collection instrument which might not validly represent the right answers due to respondents might not provide the right information in order to protect their companies' reputations. For this reason, we suggest that the collection for the same type of data need to adopt also in-depth interview, focus group discussion and observation to crosscheck all information from the respondents. Third, the study only applies a cross-sectional approach which does not consider the time effect. It is important for future researchers to use a longitudinal approach to accurately assess the impact of market orientation and firm performances as recommended by Iyer et al. (2019).

\section{REFERENCES}

Abbu, H. R., \& Gopalakrishna, P. (2019). Synergistic effects of market orientation implementation and internalization on firm performance: Direct marketing service provider industry. Journal of Business Research, (March 2018). https://doi.org/10.1016/j.jbusres.2019.06.004

Acosta, A. S., Crespo, Á. H., \& Agudo, J. C. (2018). Effect of market orientation, network capability and entrepreneurial orientation on international performance of small and medium enterprises (SMEs). International Business Review, (April), 0 1 .

Andotra, N., \& Gupta, R. (2016). Impact of Environmental Turbulence on Market Orientation - Business Performance Relationship in SSIs. Global Business Review, 17(4), 806820. 
Barney, J. (1991). Firm Resources and Sustained Competitive Advantage. Journal of Management, Vol. 17, pp. 99-120. https://doi.org/10.1177/014920639101700108

Gligor, D., Gligor, N., \& Maloni, M. (2019). The impact of the supplier' $s$ market orientation on the customer market orientation-performance relationship. International Journal of Production Economics, 216, 81-93.

Hair, J. F., Sarstedt, M., Hopkins, L., \& Kuppelwieser, V. G. (2014). Partial least squares structural equation modeling (PLS-SEM). European Business Review, 26(2), 106-121.

Hair, J., Hollingsworth, C. L., Randolph, A. B., \& Chong, A. Y. L. (2017). An updated and expanded assessment of PLSSEM in information systems research. Industrial Management \& Data Systems, 117(3), 442-458.

Henseler, J., Ringle, C. M., \& Sarstedt, M. (2015). A new criterion for assessing discriminant validity in variance-based structural equation modeling. Journal of the Academy of Marketing Science, 43(1), 115-135.

Hopkins, L. (2015). Partial least squares structural equation modeling ( PLS-SEM ) An emerging tool in business research. European Business Review, 26(2), 106-121.

Huhtala, J., Sihvonen, A., Frösén, J., Jaakkola, M., \& Tikkanen, H. (2014). Market orientation, innovation capability and business Insights from the global financial crisis. Baltic Journal of Management, 9(2), 134-152.

Idrus, S. Al, Ahmar, A. S., \& Abdussakir, A. (2019). The in fl uence of business innovation with relationship of organizational learning and job satisfaction on market orientation. Journal of Science and Technology Policy Managemen, 10(5), 997-1014.

Iyer, P., Davari, A., Zolfagharian, M., \& Paswan, A. (2019). Market orientation, positioning strategy and brand performance. Industrial Marketing Management, 81(October 2018), 16-29.

Jiang, W., Li, J., Yan, H., Li, H., \& Chen, M. (2019). Customer orientation and success in introduction of new products: an empirical study in an emerging economy. Journal of Business and Industrial Marketing, (August).

Jogaratnam, G. (2017). How organizational culture influences market orientation and business performance in the restaurant industry. Journal of Hospitality and Tourism Management, 31,

Jyoti, J., \& Sharma, J. (2012). Impact of Market Orientation on Business Performance: Role of Employee Satisfaction and Customer Satisfaction. Vision, 16(4), 297-313.

Kajalo, S., \& Lindblom, A. (2015). Market orientation , entrepreneurial orientation and business performance among small retailers. International Journal of Retail \& Distribution Management, 43(7), 580-596.

Kohli, A. K., \& Jaworski, B. J. (1990). Market Orientation: The Construct, Research Propositions, and Managerial Implications. Journal of Marketing, 54(2), 1-18.

Köhr, C. K., Corsi, A. M., Capitello, R., \& Szolnoki, G. (2019). Family culture and organisational systems as antecedents of market orientation and performance among family wineries. International Journal of Wine Business Research, 31(2), 180202.

Lim, J.-S., Darley, W. K., \& Marion, D. (2017). Market orientation, innovation commercialization capability and firm performance relationships: the moderating role of supply chain influence. Journal of Business \& Industrial Marketing, 32(7),

Mahmoud, M. A., Blankson, C., Owusu-frimpong, N., Nwankwo, S., \& Trang, T. P. (2016). Market orientation, learning orientation and business performance: The mediating role of innovation. International Journal of Bank Marketing, 34(5), 623-648.

Mahmoud, M. A., Blankson, C., Owusu-Frimpong, N., Nwankwo, S., \& Trang, T. P. (2016). Market orientation, learning orientation and business performance: The mediating role of innovation. International Journal of Bank Marketing, 34(5), 623-648.

Narver, J. C., \& Slater, S. F. (1990). The Effect of a Market Orientation on Business Profitability. Journal of Marketing, 54(4), 20-35. https://doi.org/10.2307/1251757

Nguyen, N. P. (2018a). Performance implication of market orientation and use of management accounting systems: The moderating role of accountants. Journal of Asian Business and Economic Studies, 25(1), 33-49.

Nguyen, N. P. (2018b). Performance implication of market orientation and use of management accounting systems The moderating role of accountants. Journal of Asian Business and Economics, 25(1), 23-49. https://doi.org/10.1108/JABES-042018-0005

Oduro, S., \& Haylemariam, L. G. (2019). Market orientation, CSR and financial and marketing performance in manufacturing firms in Ghana and Ethiopia. Sustainability Accounting, Management and Policy Journal, 10(3), 398-426.

Osorio Tinoco, F. F., Hernández-Espallardo, M., \& RodriguezOrejuela, A. (2019). Nonlinear and complementary effects of responsive and proactive market orientation on firms' competitive advantage. Asia Pacific Journal of Marketing

Ozdemir, S., Kandemir, D., \& Eng, T. (2017). The role of horizontal and vertical new product alliances in responsive and proactive market orientations and performance of industrial 
manufacturing firms. Industrial Marketing Management, 64, Porter, M. E. (1980). Competitive strategy: Techniques for analyzing industries and companies. In New York.

Protcko, E., \& Dornberger, U. (2014a). The impact of market orientation on business performance - the case of Tatarstan knowledge-intensive companies ( Russia ). 12(4), 225-231.

Protcko, E., \& Dornberger, U. (2014b). The impact of market orientation on business performance - the case of Tatarstan knowledge-intensive companies (Russia). Problems and Perspectives in Management, 12(4), 225-231.

Rodrigues, A. P., \& Pinho, J. C. M. R. (2010). Market orientation, job satisfaction, commitment and organisational performance The specific case of local public sector. Transforming Government: People, Process and Policy, 4(2), 172-192.

Saldanha, E. D. S., Rahyuda, I. K., Kerti Yasa, N. N., \& Sukaatmadja, I. P. G. (2018). The Role of Business Strategy in Mediating the Relationship Between Industrial Competition and Performances: A Study in the Higher Education Industry in Timor-Leste. European Journal of Business and Management, 10(8), 152-172.

Saldanha, E. D. S., Rahyuda, I. K., Yasa, N. N. K., \& Sukaatmadja, I. P. G. (2019). Persaingan Industri, Strategi Bisnis, dan Kinerja Industri. Denpasar: Udayana University Press.

Saldanha, E. de S., Rahyuda, I. K., Yasa, N. N. K., \& Sukaatmadja, I. P. G. (2018). The Role of Business Strategy in Mediating the Relationship Between Industrial Competition and Performances : A Study in the Higher Education Industry in Timor-Leste. European Jorunal of Business and Management, 10(8), 152-172.

Saldanha, E. de S., Rahyuda, I. K., Yasa, N. N. K., \&
Sukaatmadja, I. P. G. (2019). Industrial Competition, Hybrid Strategy and Industrial Performance: Study in Higher Education Industry in Timor-Leste. Journal of Engineering and Applied Sciences, 14(8), 2456-2464.

Salehzadeh, R., Khazaei Pool, J., Tabaeeian, R. A., Amani, M., \& Mortazavi, M. (2017). The impact of internal marketing and market orientation on performance: an empirical study in restaurant industry. Measuring Business Excellence, 21(4), 273-290. https://doi.org/10.1108/MBE-02-2016-0009

Šályová, S., Táborecká-Petrovičová, J., Nedelová, G., \& Ďad'o, J. (2015). Effect of Marketing Orientation on Business Performance: A Study from Slovak Foodstuff Industry. Procedia Economics and Finance, 34(15), 622-629.

Sampaio, C. A. F., Hernández-Mogollón, J. M., \& Rodrigues, R. G. (2019). Assessing the relationship between market orientation and business performance in the hotel industry the mediating role of service quality. Journal of Knowledge Management, 23(4), 644-663. https://doi.org/10.1108/JKM08-2017-0363

Valaei, N. (2017). Organizational structure, sense making activities and SMEs' competitiveness: An application of confirmatory tetrad analysis-partial least squares (CTA-PLS). VINE Journal of Information and Knowledge Management Systems, 47(1), 16-41. https://doi.org/10.1108/VJIKMS-042016-0015

Yadav, S. K., Tripathi, V., \& Goel, G. (2019). Mediating effect of innovation with market orientation and performance relationship. Management Research, 17(2), 152-167. https://doi.org/10.1108/MRJIAM-03-2018-0827

Zehir, C., Can, E., \& Karaboga, T. (2015). Linking Entrepreneurial Orientation to Firm Performance: The Role of Differentiation Strategy and Innovation Performance. Procedia - Social and Behavioral Sciences, 210, 358-367. 
Appendix A. Dimensions and Indicators of Market Orientation (OM).

\begin{tabular}{|c|c|c|c|}
\hline Dimension & Indicators & Code & Source \\
\hline \multirow{3}{*}{$\begin{array}{l}\text { Customer } \\
\text { orientation } \\
\left(\mathrm{OM}_{1}\right)\end{array}$} & $\begin{array}{l}\text { The objective of our business orientation is to create } \\
\text { value based on customers needs. }\end{array}$ & $\mathrm{OM}_{11}$ & $\begin{array}{l}\text { (Huhtala et al., 2014; Narver \& Slater, 1990; } \\
\text { Nguyen, 2018b) }\end{array}$ \\
\hline & $\begin{array}{l}\text { Our business orientation strategy can create high } \\
\text { values for the customers. }\end{array}$ & $\mathrm{OM}_{12}$ & $\begin{array}{l}\text { (Huhtala et al., 2014; Narver \& Slater, 1990; } \\
\text { Nguyen, 2018b) }\end{array}$ \\
\hline & $\begin{array}{l}\text { We put major emphasis on our commitment to answer } \\
\text { the customer needs. }\end{array}$ & $\mathrm{OM}_{13}$ & $\begin{array}{l}\text { (Huhtala et al., 2014; Narver \& Slater, 1990; } \\
\text { Nguyen, 2018b) }\end{array}$ \\
\hline \multirow{2}{*}{$\begin{array}{l}\text { Competitor } \\
\text { orientation } \\
\left(\mathrm{OM}_{2}\right)\end{array}$} & $\begin{array}{l}\text { Information about competitor activities is collected } \\
\text { regularly. }\end{array}$ & $\mathrm{OM}_{21}$ & $\begin{array}{l}\text { (Huhtala et al., 2014; Narver \& Slater, 1990; } \\
\text { Nguyen, 2018b) }\end{array}$ \\
\hline & $\begin{array}{l}\text { We put greater emphasis on improving the } \\
\text { competitive action which to threaten our business. }\end{array}$ & $\mathrm{OM}_{23}$ & $\begin{array}{l}\text { (Huhtala et al., 2014; Narver \& Slater, 1990; } \\
\text { Nguyen, 2018b) }\end{array}$ \\
\hline \multirow{3}{*}{$\begin{array}{l}\text { Inter-functional } \\
\text { coordination. } \\
\left(\mathrm{OM}_{3}\right)\end{array}$} & $\begin{array}{l}\text { We always communicate about customer needs with } \\
\text { all business units. }\end{array}$ & $\mathrm{OM}_{31}$ & $\begin{array}{l}\text { (Huhtala et al., 2014; Narver \& Slater, 1990; } \\
\text { Nguyen, 2018b) }\end{array}$ \\
\hline & $\begin{array}{l}\text { We always discuss market trending with all business } \\
\text { units. }\end{array}$ & $\mathrm{OM}_{32}$ & $\begin{array}{l}\text { (Huhtala et al., 2014; Narver \& Slater, 1990; } \\
\text { Nguyen, 2018b) }\end{array}$ \\
\hline & $\begin{array}{l}\text { Our business units are integrated to create value for } \\
\text { target customers. }\end{array}$ & $\mathrm{OM}_{33}$ & $\begin{array}{l}\text { (Huhtala et al., 2014; Narver \& Slater, 1990; } \\
\text { Nguyen, 2018b) }\end{array}$ \\
\hline
\end{tabular}

\section{Appendix B. Dimensions and Indicators of Business Performance (BP)}

\begin{tabular}{|c|c|c|c|}
\hline Dimension & Indicators & Code & Source \\
\hline \multirow{4}{*}{ Financial (DB1) } & Our return on investment increase in the last two years. & $\mathrm{DB}_{11}$ & $\begin{array}{l}\text { (Jogaratnam, 2017; Ozdemir et al. 2017; } \\
\text { Nguyen 2018). }\end{array}$ \\
\hline & Our profit increased in the last two years. & $\mathrm{DB}_{12}$ & (Nguyen, 2018b; Ozdemir et al., 2017) \\
\hline & Our sales growth increase in the last two years. & $\mathrm{DB}_{13}$ & (Nguyen, 2018b; Ozdemir et al., 2017) \\
\hline & Our total profitability increase in the last two years. & $\mathrm{DB}_{14}$ & (Ozdemir et al., 2017) \\
\hline \multirow{4}{*}{$\begin{array}{l}\text { Non Financial } \\
\text { (DB2) }\end{array}$} & $\begin{array}{l}\text { The customers' satisfaction with our product increase in } \\
\text { the last two years. }\end{array}$ & $\mathrm{DB}_{21}$ & (Protcko \& Dornberger, 2014b) \\
\hline & $\begin{array}{l}\text { Our customers' loyalty to the offering product increase in } \\
\text { the last two years. }\end{array}$ & $\mathrm{DB}_{22}$ & Protcko \& Dornberger 2014) \\
\hline & Our new customers increase in the last two years. & $\mathrm{DB}_{23}$ & Protcko \& Dornberger 2014) \\
\hline & Our market share increase in the last two years. & $\mathrm{DB}_{24}$ & $\begin{array}{l}\text { (E. de S. Saldanha, Rahyuda, Yasa, \& } \\
\text { Sukaatmadja, 2018) }\end{array}$ \\
\hline
\end{tabular}

Appendix C. Result of cross load discriminant validity test.

\begin{tabular}{|l|l|l|l|l|l|}
\hline & DB1 & \multicolumn{2}{|c|}{ DB2 } & OM1 & OM3 \\
\hline DB11 & 0.928 & 0.777 & -0.037 & -0.255 & 0.195 \\
\hline DB12 & 0.961 & 0.788 & 0.097 & 0.040 & 0.393 \\
\hline DB13 & 0.949 & 0.786 & 0.215 & 0.094 & 0.471 \\
\hline DB14 & 0.910 & 0.801 & 0.273 & 0.144 & 0.493 \\
\hline DB21 & 0.611 & 0.865 & 0.448 & 0.156 & 0.477 \\
\hline DB22 & 0.572 & 0.813 & 0.484 & 0.291 & 0.646 \\
\hline DB23 & 0.835 & 0.869 & 0.230 & 0.020 & 0.345 \\
\hline DB24 & 0.830 & 0.852 & 0.040 & -0.065 & 0.389 \\
\hline OM11 & 0.249 & 0.442 & 0.792 & 0.345 & 0.432 \\
\hline OM12 & -0.105 & 0.067 & 0.674 & 0.393 & 0.175 \\
\hline OM13 & 0.147 & 0.278 & 0.917 & 0.587 & 0.538 \\
\hline OM21 & -0.221 & -0.087 & 0.429 & 0.793 & 0.460 \\
\hline 0M22 & 0.178 & 0.230 & 0.517 & 0.902 & 0.673 \\
\hline OM31 & 0.132 & 0.282 & 0.406 & 0.609 & 0.702 \\
\hline
\end{tabular}

